\title{
QUANTIFICATION OF RESPIRATORY PARAMETERS IN PATIENTS WITH TEMPORAL LOBE EPILEPSY
}

\author{
Fulvio Alexandre Scorza', Ana Maria Fonseca Abreu', \\ Marly de Albuquerque ${ }^{2}$, Julio B Cota Pacheco², Renato Breviglieri', \\ Josemir Wanderley Sander ${ }^{4}$ Antônio Carlos da Silva ${ }^{3}$, \\ Esper Abrão Cavalheiro', Ricardo Mario Arida ${ }^{3}$
}

\begin{abstract}
Dysfunction affecting cardiac or pulmonary systems has been postulated as a major factor in sudden death in epilepsy (SUDEP). Whilst the majority of studies of cardiorespiratory function have focused on changes during seizures, here we investigate whether epilepsy influences basal respiratory parameters in patients with temporal lobe epilepsy (TLE) during the interictal period. Spirometry was performed in 10 females and 10 males. Measurements of Vital Capacity (VC), Forced Vital Capacity (FVC), Forced Expiratory Volume in the first second (FEV1) and ratios of FEV1 to FVC (FEV1/FVC) were obtained, and these values were analyzed as percentages of predicted values. None of the patients had chronic obstructive pulmonary disease and no significant alterations in respiratory function tests were found among these patients. No association between seizure frequency, antiepileptic drugs and SUDEP could be found in this study. Although the study did not identify any specific respiratory abnormality in TLE patients during the interictal period, re-evaluation of clinical data on pulmonary disorders in people with epilepsy should be better investigated.
\end{abstract}

KEY WORDS: epilepsy, SUDEP, respiratory parameters.

\section{Quantificação de parâmetros respiratórios em pacientes com epilepsia do lobo temporal}

RESUMO - Alterações cardíacas e pulmonares têm sido propostas como principais fatores de risco no fenômeno da morte súbita em epilepsia (SUDEP). Enquanto a maioria dos estudos tem verificado as alterações da função cardiorrespiratória durante as crises epilépticas, nosso estudo avaliou a função pulmonar de indivíduos com epilepsia do lobo temporal (ELT) no período interictal. Vinte pacientes com ELT (10 homens e 10 mulheres) participaram de nosso estudo. Nos testes de função pulmonar foram mensurados os seguintes parâmetros: Capacidade Vital Forçada (CVF), Capacidade Vital Lenta (CVL), Volume Expiratório Forçado no primeiro segundo (VEF1) e o Índice VEF1/CVF. Os resultados foram comparados aos valores de normalidade preditos na literatura. Nenhum dos pacientes apresentou doença pulmonar obstrutiva ou restritiva e alterações significativas nos testes de função pulmonar. Não foram encontradas associações entre a freqüência de crises, drogas antiepilépticas e SUDEP. Embora nosso estudo não tenha identificado qualquer anormalidade respiratória específica em indivíduos com ELT durante o período interictal, os dados clínicos sobre transtornos pulmonares em indivíduos com epilepsia devem ser melhor avaliados.

PALAVRAS-CHAVE: epilepsia, SUDEP, parâmetros respiratórios.

Sudden unexplained death in epilepsy (SUDEP) is a major cause of mortality in patients with epilepsy ${ }^{1,2}$. The aetiology of SUDEP remains unclear and may be multifactorial. Autonomic dysfunction affecting cardiac or pulmonary systems has been postulated as a major factor in SUDEP. Cardiac rate and rhythm disturbances and respiratory abnormalities have been identified during seizures ${ }^{3-6}$. Seizures can alter respiratory rate and pattern, producing tachypnoea, hypopnoea or apnoea, and secretions. Apnoea is com-

\footnotetext{
'Laboratório de Neurologia Experimental, Universidade Federal de São Paulo/Escola Paulista de Medicina, São Paulo, Brasil (UNIFESP/ EPM); ${ }^{2}$ Laboratório de Neurociências, Núcleo de Pesquisas Tecnológicas / Universidade de Mogi das Cruzes, São Paulo, Brasil (NPT / UMC); ${ }^{3}$ Departamento de Fisiologia. Universidade Federal de São Paulo/Escola Paulista de Medicina, São Paulo, Brasil (UNIFESP/EPM); ${ }^{4}$ Department of Clinical and Experimental Epilepsy, Institute of Neurology, University College of London, London, UK. Research supported by CNPq, FAPESP, CAPES and FAEP. A.M.Abreu is fellowship from CNPq.
}

Received 23 October 2006, received in final form 16 January 2007. Accepted 28 February 2007. 
mon during tonic-clonic seizure and brief apnoea occurs during many complex partial seizures ${ }^{4}$. Studies using video-EEG monitoring have shown pulmonary dysfunction in patients with epilepsy when a life-threatening period or death occurs ${ }^{7-9}$. Pulmonary oedema is the result of an increase in pulmonary vascular pressure from increased sympathetic activity, provoking the combination of pulmonary vasoconstriction and increased left atrial pressure from systemic hypertension. Status epilepticus and repetitive seizures can cause pulmonary oedema, which can alter pulmonary function for up to 72 hours $^{10}$. Studies have shown that seizure-associated respiratory compromise due to hypoventilation or obstructive apnoea is an important feature in SUDEP ${ }^{4,11}$. In a series of 15 witnessed SUDEPs, respiratory difficulties were seen in $12^{11}$. Although various abnormalities in pulmonary cardiac functions that can cause sudden death during the ictal period in patients with epilepsy have been reported ${ }^{12-14}$, there are only a few reports with respect to the interictal period ${ }^{15}$.

We aimed to assess whether patients with epilepsy have higher respiratory co-morbidity than the general population, and whether the prevalence of respiratory co-morbidity differs between people with epilepsy with and without known risk factors for SUDEP. Whereas most available studies of cardiorespiratory function have focused on changes during seizures $^{5,13}$, here we investigate whether epilepsy influences pulmonary function. We analyzed respiratory parameters in patients with temporal lobe epilepsy (TLE), the most frequent refractory epilepsy, during the interictal period.

\section{METHOD}

Adult outpatients with medically proven TLE were invited to participate as study subjects during a routine visit to a specified neurological outpatient clinic (Itapeti Neuroclinic, Mogi das Cruzes, Brazil). Patients were informed about the procedures of the study, and if agreed to take part in the study signed an informed consent form. The study was ethically reviewed and approved by the Institutional Human Research Ethics Committee.

Inclusion criteria were age over 18 years, a reliable diagnosis of TLE, ability to read and comprehend the meaning of the questionnaire and able to provide informed consent to participate in the study. Patients with a clinical diagnosis of asthma, allergic rhinitis, smoking habits, and other respiratory disorders were excluded. All had a multidisciplinary evaluation, including history and physical examination, EEG monitoring and magnetic resonance imaging (MRI). In brief, thirteen patients presented psychic seizures within complex partial seizures: nine with epigastric aura and four with affective manifestations of fear. These events occurred before anti-epileptic drugs (AED) treatment. EEG analysis with scalp electrodes performed during sleep and wakefulness showed epileptiform activity with spike waves predominantly in the anterior temporal region in nine patients, focal EEG slowness in the temporal regions in two patients and normal EEG in nine patients. MRI showed hippocampal atrophy in nine patients.

Spirometry was performed in 10 females and 10 males. All completed a questionnaire about age, sex and health habits. Body measurements were taken, including standing height and weight. After explanation of the test procedures, every subject attempted to perform spirometric manoeuvres. Forced expiratory manoeuvres were recorded with a pneumotachograph (Koko Spirometer). A minimum of 3 acceptable and reproducible manoeuvres were obtained for each patient, according to the standards recommended by the American Thoracic Society ${ }^{16}$. All spirometric examinations were carried out with the subject seated, wearing a nose clip and using a disposable mouthpiece. The technical procedures, acceptable criteria, and reproducibility followed American Thoracic Society guidelines ${ }^{17}$. Measurements for Forced Vital Capacity (FVC), Forced Expiratory Volume in the first second (FEV1) and ratios of FEV1 to FVC (FEV1/FVC) were obtained, and these values were compared with predicted values. Reference values from $\mathrm{Crapo}^{18}$ and Rodrigues ${ }^{19}$ were used.

Statistical analysis - Statistical analysis was done by employing the ANOVA test with Tukey post test. Significance was established at the $p<0.05$ level.

\section{RESULTS}

None of the 20 patients with TLE had chronic obstructive pulmonary disease. Anthropometrics and clinical characteristics of the patients with epilepsy in the study are shown in the Table. The mean age of the patients was $41 \pm 12.3$ years and the mean duration of epilepsy was $20 \pm 9$ years. All patients were treated with AEDs, using at least one medication at the time of the study. Carbamazepine (80\%) was the most commonly used AED, followed by clobazam (10\%). Almost all patients presented with controlled seizures. Pulmonary function of patients with epilepsy showed no significant alterations in respiratory tests: FVC $(4.09 \pm 1.24)$, FEV1 $(3.33 \pm 1.03)$ and FEV1/FVC (0.81 \pm 0.05$)$. No association between seizure frequency, AED and altered pulmonary function was found.

\section{DISCUSSION}

Potential mechanisms of SUDEP comprise cardiac arrhythmia, autonomic imbalance, hypoxia, arrhyth- 
Table. Anthropometrics and clinical characteristics of the patients with temporal lobe epilepsy.

\begin{tabular}{|c|c|}
\hline \multicolumn{2}{|l|}{ Sex } \\
\hline Male & 10 \\
\hline Female & 10 \\
\hline Age (years-SD) & $41 \pm 12.3$ \\
\hline Weight (Kg-SD) & $70.3 \pm 16.5$ \\
\hline Height (cm-SD) & $167.7 \pm 11.6$ \\
\hline Mean duration of epilepsy (years) & $20 \pm 9$ \\
\hline \multicolumn{2}{|l|}{ Seizure frequency } \\
\hline Controlled & 13 \\
\hline Weekly & 2 \\
\hline Monthly & 5 \\
\hline \multicolumn{2}{|l|}{ Seizure type } \\
\hline SPS & 0 \\
\hline CPS & 18 \\
\hline SPS/CPS & 2 \\
\hline \multicolumn{2}{|l|}{ AED } \\
\hline Carbamazepine & $12(60 \%)$ \\
\hline Oxcarbazepine & $4(20 \%)$ \\
\hline Divalproex & $1(5 \%)$ \\
\hline Phenobarbital & $1(5 \%)$ \\
\hline Clobazam & $5(25 \%)$ \\
\hline Clonazepam & $3(15 \%)$ \\
\hline Nitrazepam & $2(10 \%)$ \\
\hline Hidantoine & $1(5 \%)$ \\
\hline \multicolumn{2}{|l|}{ Therapy treatment } \\
\hline Monotherapy & 10 \\
\hline Polytherapy & 10 \\
\hline
\end{tabular}

SPS, simple partial seizure; CPS, complex partial seizure.

mogenic drugs or central or obstructive apnoea ${ }^{4,20-22}$. We analyzed respiratory parameters in patients with TLE during the interictal period and found no significant alterations in respiratory function tests.

The exact pathomechanism of SUDEP is unknown. Cardiac mechanisms may play a role, due to repetitive cardiac damage during seizures and to arrhythmia during seizures, possibly triggered by apnoea and/ or cerebral autonomic imbalance. Several studies deal with respiratory parameters during seizures ${ }^{4,15,23}$ but information on respiratory function in patients with epilepsy during the interictal period is lacking. One study ${ }^{15}$ found vital capacity levels to be significantly lower in patients with generalized epilepsy than in those with partial epilepsy. Respiratory physicians detected no pathology during examinations of patients, so the differences found in vital capacity were evaluated as a lack of coordination in respiratory function tests. Another group also observed that respiratory function tests in the interictal period were no different from those of a control group ${ }^{14}$. Information about the interictal period was also analysed in animals with pilocarpine-induced epilepsy ${ }^{24}$. In this study rats with epilepsy presented an altered ability to compensate for changes in arterial gas levels with changes in ventilation in response to an increase or decrease in $\mathrm{PaCO}_{2}$.

Although data from literature have showed seizure control in $10-40 \%$ of TLE patients, we observed that $75 \%$ of the patients from our study presented controlled seizure under therapy treatment. One explanation for our findings might be that most patients in this study had controlled seizures, and increased seizure frequency is reported to be a strong risk factor for SUDEP. Most of our patients, however, were taking AED polytherapy, another known risk factor for SUDEP.

Several autopsy studies in people with SUDEP have reported pulmonary oedema ${ }^{25}$ or increased lung weights ${ }^{14}$. The post-mortem data in one study ${ }^{26}$ revealed bronchial fluid or pulmonary oedema in four of six cases, suggesting that the increased autonomic stimulation associated with seizures in SUDEP observed in their study may contribute to pulmonary changes that may be important in SUDEP; pre-existing pulmonary diseases could exacerbate this process.

It might be speculated that ictal as well as interictal ventilatory dysfunction could have a role in some SUDEP cases. Although our study did not identify any specific common respiratory abnormality in TLE patients during the interictal period, re-evaluation of clinical data about pulmonary disorders in people with epilepsy should be better investigated.

\section{REFERENCES}

1. Nashef L, Fish DR, Garner S Sander JW, Shorvon SD. Sudden death in epilepsy: a study of incidence in a young cohort with epilepsy and learning difficulty. Epilepsia 1995;36:1187-1194.

2. Ficker DM, So EL, Shen WK, et al. Population-based study of the incidence of sudden unexplained death in epilepsy. Neurology 1998;51: $1270-1274$.

3. Marshall DW, Westmoreland BF, Sharbrough FW. Ictal tachycardia during temporal lobe seizures. Mayo Clin Proc 1983;58:443-446.

4. Nashef L, Walker F, Allen P, Sander JWAS, Shorvon SD, Fish DR. Apnoea and bradycardia during epileptic seizures: relation to sudden death in epilepsy. J Neurol Neurosurg Psychiatry 1996;60:297-300.

5. Blum AS, Ives JR, Goldberger AL, Al-Aweel IC, Krishnamurthy KB, Drislane FW, Schomer DL. Oxygen desaturations triggered by partial seizures: implications for cardiopulmonary instability in epilepsy. Epilepsia 2000;41:536-541.

6. Tigaran S, Molgaard H, McClelland R, et al. Evidence of cardiac ischemia during seizures in fdrug refractory epilepsy patients. Neurology 2003;60:492-495.

7. So EL, Sam MC, Lagerlund TL. Postictal central apnea as a cause of SUDEP: evidence from near-SUDEP incident. Epilepsia 2000;41:1494-1497. 
8. Ficker DM. Sudden unexplained death and injury in epilepsy. Epilepsia 2000;41(Suppl 2):S7-S12.

9. Swallow RA, Hillier CE, Smith PE. Sudden unexplained death in epilepsy (SUDEP) following previous seizure-related pulmonary oedema: case report and review of possible preventative treatment. Seizure 2002;11:446-448.

10. Devinsky O. Effects of seizures on autonomic and cardiovascular function. Epilepsy Curr 2004;4:43-46.

11. Langan $Y$, Nashef L, Sander JWAS. Sudden unexpected death in epilepsy: a series of witnessed deaths. J Neurol Neurosurg Psychiatry 2000; 68:211-213.

12. Koppel BS, Pearl M, Perla E. Epileptic seizure as a cause of unilateral pulmonary edema. Epilepsia 1987;28:41-44.

13. Simon RP, Bayne LL, Tranbaugh RF, Levis FR. Elevated pulmonary lymph flow and protein content during status epilepticus in sheep. J Appl Physiol 1982;52:91-95.

14. Terrence CF, Rao GR, Perper JA. Neurogenic pulmonary edema in unexpected unexplained death in epileptic patients. Ann Neurol 1981;9: 458-464.

15. Berilgen MS, Sari T, Bulut S, Mungen B. Effects of epilepsy on autonomic nervous system and respiratory function tests. Epilepsy Behav 2004; 5:513-516.

16. American Thoracic Society. Standardization of spirometry. Am J Respir Crit Care Med 1995;152:1107-1136.
17. American Thoracic Society. Pulmonary Rehabilitation. Am J Respir Crit Care Med 1999;159:1666-1682.

18. Crapo, RO. Pulmonary function testing. N Engl J Med 1994;331:25-30.

19. Rodrigues R Jr. I Consenso brasileiro de espirometria. São Paulo: SBPT, 1996.

20. Natelson BH, Suarez RV, Terrence CF, Txrizo R. Patients with epilepsy who die suddenly have cardiac disease. Arch Neurol 1998;55:857-860.

21. Hilz MJ, Devinsky O, Doyle W, Mauerer A, Dutsch M. Decrease of sympathetic cardiovascular modulation after temporal lobe epilepsy surgery. Brain 2002;125:985-995.

22. Lathers CM, Schraeder PL. Clinical pharmacology: drugs as a benefit and / or risk in sudden unexpected death in epilepsy? J Clin Pharmacol 2002;42:123-136.

23. Walker F, Fish DR. Recording respiratory parameters in patients with epilepsy. Epilepsia 1997;38(Suppl 11):S41-S42.

24. Campos RR, Tolentino-Silva FRP, Mello LEAM. Respiratoy pattern in a rat model of epilepsy. Epilepsia 2003;44:712-717.

25. Antoniuk SA, Oliva LV, Bruck I, Malucelli M, Yabumoto S, Castellano JL. Sudden unexpected, unexplained death in epilepsy autopsied patients. Arq Neuropsiquiatr 2001;59:40-45.

26. Nei M, Ho RT, Abou-Khalil BW, et al. EEG and ECG in sudden unexplained death in epilepsy. Epilepsia 2004;45:338-345. 